\title{
Natural durability of acetylated OSB in ground stake test: total decay after 102 months of testing
}

\author{
Natürliche Dauerhaftigkeit acetylierter OSB-Proben im Erdkontakt: vollständige Zerstörung nach 102-monatiger \\ Prüfung
}

Antonios N. Papadopoulos

Received: 8 March 2011 / Published online: 21 April 2011

(C) Springer-Verlag 2011

\begin{abstract}
Acetylated OSB stakes were tested in ground contact in Western Greece. Two levels of acetylation were used, a high and a low level of $20.4 \%$ and $11.2 \%$ acetyl content, respectively. The highly acetylated stakes showed severe attack after 96 months and total decay after 102 months of testing.
\end{abstract}

\section{Introduction}

Chemical modification has been used to improve decay resistance of both wood and wood based panels. The majority of researches investigating this area has been concerned with the reaction of acetic anhydride since it is well documented that acetylation imparts excellent protection against decay. The purpose of this paper was to report on the performance of acetylated OSB in ground stake test.

\section{Experimental}

The acetylation of fir strands (Picea abies), the laboratory manufacture of OSB and the ground stake test is described in detail in a previous paper (Papadopoulos 2006).

\section{Results and discussion}

It was reported earlier (Papadopoulos 2006, 2009) that the control stakes were totally decayed after four years and the

\footnotetext{
A.N. Papadopoulos $(\bowtie)$

Branch of Drama, Department of Forestry and Management of

Natural Environment, Laboratory of Wood Science and

Technology, Technological Educational Institute of Kavala,

66100 Drama, Greece

e-mail: antonios1974@hotmail.com
}

Table 1 Decay rating of control and acetylated OSB in ground stake test (a rating of 10 means no decay, 9 slight decay, 7 moderate decay, 4 severe decay and 0 total decay)

Tab. 1 Zerstörungsgrad der Kontroll- und acetylierten OSB-Proben im Erdkontakt $(10=$ nicht zerstört, $9=$ leicht zerstört, $7=$ mäßig zerstört, $4=$ stark zerstört, $0=$ vollständig zerstört)

\begin{tabular}{llll}
\hline Exposure time & \multicolumn{2}{l}{ Decay rating } & \\
\cline { 2 - 4 } & Control & $\begin{array}{l}\text { Acetylated } \\
(11.2 \%)\end{array}$ & $\begin{array}{l}\text { Acetylated } \\
(20.4 \%)\end{array}$ \\
\hline 12 months & 10 & 10 & 10 \\
24 months & 7 & 10 & 10 \\
36 months & 4 & 7 & 10 \\
48 months & 0 & 4 & 10 \\
60 months & 0 & 4 & 7 \\
72 months & 0 & 0 & 7 \\
84 months & & & 4 \\
96 months & & & 4 \\
102 months & & & 0 \\
\hline
\end{tabular}

low-acetylated stakes after six years of testing. On the other hand, the high-acetylated stakes showed moderate decay (upper part of Table 1). The lower part of the Table presents the new data. It can be seen that the high-acetylated stakes showed severe decay after 96 months and total decay after 102 months in ground stake test.

\section{References}

Papadopoulos AN (2006) Decay resistance of acetylated OSB in ground stake test. Holz Roh- Werkst 64:245-246

Papadopoulos AN (2009) Decay resistance in ground stake test of acetylated OSB in ground stake test. Eur J Wood Prod 67:365366 